\section{Media right to report small value of antidepressants}

SIR - Your Editorial 'No more scavenger hunts' (Nature 452, 1; 2008) indicates that the press reaction to a recent meta-analysis of antidepressant efficacy was exaggerated and that it was "not the media's finest hour". But I do not find their reaction surprising.

To one who has followed the scientific literature over the years, the fact that antidepressants' superiority over placebo is at best modest may come as no surprise: in fact, this is apparent in most published clinical trials. But the portrayal of antidepressants as advertised by pharmaceutical companies, ratified by medical professionals, propagated by mass media and absorbed by the general public during the past two decades has been very different. They are promoted as highly efficacious drugs (not true, when considering effect magnitude) that correct the 'chemical imbalances' underlying depression (not true, when considering how little we know about its pathophysiology) and improve depressive symptoms better and faster than psychotherapy (not true, when considering most clinical trials that compare the two). This publicity prompted an even more misguided rejection of antidepressant therapy by some of its opponents, with claims that the drugs would 'dope' people into happiness and prevent them from working out their problems.

Publicizing the modest effects of antidepressants goes some way towards countering the much more exaggerated positive hype that preceded it. Although it might not have been the media's finest hour, on this subject it was still finer than most.

\section{Olavo B. Amaral}

Departamento de Bioquímica, ICBS, Universidade Federal do Rio Grande do Sul, R. Ramiro Barcelos 2600 (anexo), 90035-003 Porto Alegre, RS, Brazil

\section{Tropical farmers need productive alternatives}

SIR - Your Editorial 'Markets can save forests' (Nature 452, 127-128; 2008) proposes integrating deforestation into the international carbon market, but it is unlikely that money alone can solve the problem.

The process of tropical deforestation presents a dilemma: enormous economic value (more than US $\$ 2,000$ a year per hectare) is lost in favour of small private benefits (often less than US\$100 a year per hectare). In a true market, an increased, scarcity-signalling price should provide an incentive to boost the supply of the scarce commodity. So far, this has not worked in the case of tropical forests. Real financial flows received for the provision of ecosystem services are vanishingly small, if they exist at all - only a few beneficiaries have been convinced to pay for environmental services. This illustrates the essentially theoretical character (at least, up till now) of economic values generated by ecosystem services.

'Payments for ecosystem services' are supposed to save tropical forests. But even if it were possible to mobilize substantial payments, tropical farmers wouldn't be prepared to stand by and twiddle their thumbs while receiving them. They need a field of activity, so sustainable landuse concepts should address the social environment and needs of people as well. These concepts could be linked and possibly financed by such payments.

If the people who use tropical lands are disregarded, we don't believe that payments for ecosystem services will solve the problem of disappearing tropical forests. What is needed is an economic system that keeps people gainfully employed in an activity that is ultimately productive, not destructive.

Thomas Knoke ${ }^{\star}$, Bernd Stimm $\dagger$, Michael Weber ${ }^{\dagger}$ *Institute of Forest Management,

Technische Universität München

†Institute of Silviculture,

Technische Universität München,

Am Hochanger 13, 85354 Freising, Germany

\section{Researchers should explain why they use animals}

SIR - Your News story 'Animal-rights activists invade Europe (Nature 451, 1034 $1035 ; 2008$ ) highlights the need for medical researchers to do more to communicate to the public the reasons why they need to use animals in their research and what this involves. All too often, there is a tendency to wait until extremism becomes intolerable before taking steps to counter it (see Nature 452, 282; 2008). The little information about animal research available to the public is frequently oversimplified and tends to be over-reliant on the perceived authority of the author. The scientific literature usually requires subscription to access it and scientific training to understand it. This leaves information gaps through which antivivisectionist groups can push their propaganda.

Organizations such as the Research Defence Society (www.rds-online.org.uk) do much to address this deficit, but have limited resources and cannot be expected to counter the animal-rights campaigners alone. Anyone who is wondering why somebody doesn't debunk misleading claims made about them or their colleagues should consider the possibility that they are that 'somebody'. Even those who are not prepared to go public can always provide detailed explanations of their work and that of others in the field to scientific advocacy campaigns.
A fact your report didn't mention is that the new biomedical laboratory in Oxford - which, by the way, will house mostly rodents and very few monkeys - has been built. In a campaign that complemented the efforts of the police and government, ProTest were able to counter the animal-rights group Speak ('The voice for the animals') by capitalizing on the overwhelming support for the new laboratory among Oxford students and local politicians.

Extremism can be defeated, but only if scientists stand up and expose the myths and distortions that fuel it.

Name and address supplied

\section{Truth about a plant with many names}

SIR - In the portrayal in Books \& Arts of the University History Museum in Pavia, northern Italy (Nature 451, 526, 2008), the naturalist Giovanni Antonio Scopoli - one of Pavia's many famous professors - is linked with the drug scopolamine. But although the two are connected, the compound was in fact named after the plant from which it is derived, Scopolia carniolica.

Indeed, Scopoli (1723-1788) was also a physician. He worked for a time at the huge 500 -year-old mercury mine in Idrija in Carniola, now part of Slovenia, and recorded the adverse effects of mercury in miners. In this mountainous region, he studied the local plants and published his findings in the famous Flora Carniolica in 1760 and 1772, and corresponded in Latin with the Swedish naturalist Carl Linnaeus.

The scopolamine-containing plant was first described in 1569 by Pietro Andrea Mattioli and was identified by Scopoli in the forests around Idrija as Lithophila. The Vienna court botanist Nikolaus Joseph von Jacquin in 1764 changed the name to Scopola carniolica, in honour of the great naturalist. However, Scopoli avoided using the name, as 'scopola' is an insult in Venetian dialect, indicating a slap in the face. Linnaeus changed the name to Hyoscyamus scopolia in 1767, and in 1790 the genus name Scopolia was adopted.

About 100 years later, Ernst A. Schmidt at the University of Marburg isolated an alkaloid constituent from Scopolia carniolica's dried rhizome, naming the drug scopolamine. This sedative has also been used by ophthalmologists and as a 'truth serum' during the Cold War.

\section{Marko Kreft, Robert Zorec}

Laboratory of Neuroendocrinology-Molecular Cell Physiology, Institute of Pathophysiology, Faculty of Medicine, University of Ljubljana, Zaloška 4, 1000 Ljubljana, Slovenia, and Celica Biomedical Center, Tehnološki Park 24, 1000 Ljubljana, Slovenia 